\title{
THE LEADER-MEMBER EXCHANGE ROLE IN THE MEDIATION RELATIONSHIP OF THE ROLE OF STRESS TOWARDS TURNOVER INTENTION WITHIN COOPERATIVES IN THE REGENCY OF TABANAN
}

\author{
Satrya I Gusti Bagus Honor, Wibawa I Made Artha, Sudharma I Nyoman \\ Faculty of Economics and Business, University of Udayana, Bali, Indonesia \\ ${ }^{*}$ E-mail: satrya 567@hotmail.com
}

\begin{abstract}
Cooperatives represents one of the main driving forces of economic development on the basis of a local economy. The forward and backward movements of a 'Cooperative' can be affected from the level 'Role of Stress' for employees and 'Leader - Member Exchange' within an organisation. Employees are categorised as important assets within the 'Cooperatives' in which needs to be managed well to ensure reductions of costs that emerge due to factors of finding new employees. From this it is needed to understand the factors involved that can effect the occurance of 'Turnover Intention'. This research is undertaken to determine the role of 'Leader-Member Exchange', in regards to the mediation of the 'Role of Stress' towards the 'Turnover Interntion' of employees. This research is undertaken through using 75 (seventy five) Cooperatives in the Regency of Tabanan. The data gathering is undertaken through the spreading of quesionaires that uses a 5 points Likert scale to measure 12 (tweleve) questions. The analysis technique that is applied is the 'Path Analysis'with the method of analysis using the Partial Least Square (PLS). The result of this research will help indicate (1) Role of Stress having a positive effect and significance towards the Turnover Intention, (2) Role of Stress having a negative effect and siginificance towards Leader-member Exchange, (3) Leader-Member Exchange having a negative effect and significance towards Turnover Intentions, (4) Leader-Member Exchange mediating partially the effect on Role of Stress that can effect Turnover Intention.
\end{abstract}

\section{KEY WORDS}

Cooperatives, role stress, leader-member exchange, turnover intention.

The economic development on the island of Bali specifically the finance sector, $t$ this time has made significant progress. In regards to the finance sector, therefore one of the main supporters to this is 'Cooperatives'. Cooperatives are considered a main supporter of the economy due to playing a vital role in the development of local economies in regards to support of the development for small and medium enterprises (SME's). Human resources currently represents the main success factor to services provided by cooperatives. This is due to the fact that cooperatives are considered a service company that puts forward the quality of its human resources to attain long term company goals.

The development of cooperatives at this moment is supported by the development of SME's in Bali that have increased. The data provided by the Central Bureau of Statistics (Data Badan Pusat Statistik (BPS)) in the year of 2014 has shown that, 98 percent proprotion of the indonesian society are in the scale of small and medium enterprises. That matter has indicated a very large portion, in which in the same year has shown that 97 percent of the total labour absorbed in the SME's sector that contributes to the total number of labour availability and contributions towards the Gross Domestic Product (GDP) achieving 54-57 percent. The magnitude of the proportion of labour absorption does not mean it does not encounter problems or challenges. Several aspects that are considered challenges are for examples access to funding, access to technology and information, access to markets, the level of professionalism amongst human resources, and appropriate organisational competence in undertaking managerial duties.

The advancement and health of a cooperative is determined by the level of performance of its employees, interpersonal relationships between employees, and the 
managers roles in motivating employees effectively that can directly effect the welfare of cooperative members. As for the number of new cooperatives that are considered active and not active including the total number of members in the regency of Tabanan from the years 2011-2015 can be shown on Table 1 as follows:

Table 1 - The Development of Cooperatives in the Regency of Tabanan

\begin{tabular}{|c|c|c|c|c|c|c|}
\hline Year & Active & $\begin{array}{c}\text { Not } \\
\text { Active }\end{array}$ & Total & $\begin{array}{c}\text { Members } \\
\text { (People) }\end{array}$ & $\begin{array}{c}\text { Asset } \\
\text { (Rupiah) }\end{array}$ & $\begin{array}{c}\text { SHU } \\
\text { (Rupiah) }\end{array}$ \\
\hline 2012 & 468 & 47 & 515 & 74.217 & 658.369 .000 .000 & 9.558 .000 .000 \\
\hline 2013 & 478 & 53 & 531 & 78.044 & 708.044 .000 .000 & 12.460 .000 .000 \\
\hline 2014 & 493 & 50 & 538 & 79.935 & 901.188 .739 .227 & 16.791 .428 .480 \\
\hline 2015 & 506 & 43 & 549 & 83.766 & 1.233 .724 .994 .985 & 21.976 .033 .111 \\
\hline 2016 & 524 & 35 & 559 & 89.077 & 1.196 .753 .652 .490 & 28.559 .621 .480 \\
\hline
\end{tabular}

Source: Dinas Koperasi dan UMKM Kabupaten Tabanan, 2017.

As shown in Table 1 it can be viewed that there is a significant increase in the number of cooperatives in the Regency of Tabanan in regards the total number of cooperatives and assets of cooperatives that also include SHU( Sisa Hasil Usaha) or the remainder of the annual proceeds. Other than that, the Regency of Tabanan has also recieved an appreciation of the Paramadhana Madya of Cooperatives in the year of 2011 as a regency that is considered a driver of cooperatives. In the year 2014, the Regency of Tabanan also recieved the same appreciation from the Ministry of Cooperatives and Small, Medium Enterprises of the Republik of Indonesia.

In the year of 2016, in accordance with the regulations of the Ministry of Cooperatives and Small, Medium Enterprises of the Republic of Indonesia No.20/Per/M.KUKM/XI/2015 it is recorded that 75 cooperatives that are assessed from the District of Tabanan in which come from all sub-districts. The number of cooperatives assessed per sub-district for the year 2016 are as shown on Table 2 as follows:

Table 2 - The Number of Cooperatives Assessed Per Sub-District of the Year 2016

\begin{tabular}{|c|c|c|}
\hline No & Sub-District & Number \\
\hline \hline 1 & Kediri & 12 \\
\hline 2 & Tabanan & 20 \\
\hline 3 & Penebel & 12 \\
\hline 4 & Marga & 10 \\
\hline 5 & Baturiti & 4 \\
\hline
\end{tabular}

\begin{tabular}{|c|c|c|}
\hline No & Sub-District & Number \\
\hline \hline 6 & Kerambitan & 5 \\
\hline 7 & Selemadeg & 3 \\
\hline 8 & Selemadeg Barat & 4 \\
\hline 9 & Selemadeg Timur & 3 \\
\hline 10 & Pupuan & 2 \\
\hline
\end{tabular}

Source: Dinas Koperasi UMKM Kabupaten Tabanan, 2017.

As shown in Table 2 it is indicated that out of the 75 cooperatives assessed only 16 cooperatives are categorised as healthy, 57 cooperatives are categorised as reasonably healthy and 2 cooperatives categorised as unhealthy. According to the predicate and assessments that have been determined by the Dinas Koperasi (Cooperative Services) of the city of Tabanan district of the year 2016, stated that the achivement of all the cooperatives assessed is considered healthy but can not be separated from the realisation achieved in the annual budget of employees income for 2016 or the target in which has previously been determined.

The initial pre-research and through short duration interviews through observation and asking direct questions of 12 people who are employees of cooperatives during a rest period. From the 12 employees that were interviewed, there were 8 people who are cooperative employees that have stated an intention to change jobs or find other types of employment on the basis that there was an uneven workload given in comparison to work that was described in the job description, furthermore 6 people out of the 12 who are cooperative employees also stated that were encountering stress in which make it possible for employees to consider thinking or having the intention of changing employment. Other than that, there is still indication of overlapping between managers and employees in which the head of each 
department does not recieve any input or advice from lower level employees, due to fear of voicing their opinions or even ideas. The rest, in which include 4 employees still stated that support from every organisation they work for is still lacking, this lack of support from the organisation has caused the feeling of having an intention to change organisations or to other companies.

Symptoms causing employees to have thoughts of an intention to change companiesin theory is categorized as the theory of Turnover Intention. This situation has become a very important issue in the working world specifically for employees, this is caused mainly by inequality and the relationship towards the organisation. Ahsan, et al, (2013) stated that turnover intention is a desire from an employee to change jobs from one company to another. Furthermore, Hopkins et al, (2010) stated that in order to reduce turnover intention for employees within an company can be undertaken through fostering good relationships between employees, supervisors and managers. The failure by companies in managing individuals can cause a tendency to create high turnover intention within a company.

Support and good relations with company management or manager or supervisors can help reduce the risk of turnover by employees (Kim dan Michàlle, 2014). Other researchers like Gouldner, (1960), in theory of social exchange stated that when a person initiates kindness to other people, the person giving the kindness is expecting the same treatment in the future. Based on that thought it is presumed that attitude and behavior of employees is dependent upon how they percieve equality in social interactions that occur within every organisation they work for.

Hopkins et al, (2010) stated that the goal that has been set may not be achieved due to problems and pressures that are recieved, in the end may cause employees to have an intention to change jobs to another company. This matter is caused by the workload and level of responsibility that the employees are given in which can cause increased work stress for employees. Shahzad et al, (2011) also stated a similar opinion put forward which indicates that stress has a positive correlation towards high turnover intentions in employees. Firth et al, (2004) research stated that the role of stress not only does it have a direct effect towards dissatisfaction of work, but also a significant variable to a large degree contribution towards turnover intention that occurs within organisations.

Yefei et al, (2015) research indicated that the Role of Stress that is categorized as severe can cause employees to suffer from feeling lethargic at work and inturn can cause the desire for employees to change or find a better job. Zulhartini (2010) mentioned that the role of stress can cause employees to have an intention to exit the company because of the not suitable work conditions given by new management and this can create stress that may not benefit the individual employee.

Leader-member exchange (LMX) is considered in the theory of social exchange (Kim dan Michàlle, 2014). Yimo Shen et al, (2014) argue that leader-member exchange is an improvement in quality of relationships between supervisors and employees, however in reality the relationship between the employees and supervisors is not always good in which can cause employees not to last within the company. Previous research indicates that leader-member exchange has a positive relationship to the employee behavior (CherynyakHai dan Tziner, 2014). Gerstner and Day (1997) research validations indicated that high quality LMX can contribute to achiving results at work that are easier to attain, increased productivity, and a reduction in the intention of employees wanting to stop or quit their jobs.

Through observation and pre-research at the condition of Cooperatives in the District of Tabanan itself, it is indicated the need to undertake research on the role Leader-member exchange $(L M X)$ as the mediator to influence the Role of Stress towards Turnover Intention. This research is undertaken witin cooperatives, remembering that cooperatives play a vital role that is considered strategic in the economic development of communities.

Research undertaken by Desiana dan Soetjipto (2006), has found that the stressors role which consists of role overload, role conflict, dan role ambiguity are related to dissatisfaction and turnover intention for employees. In other words, the level of stress that is high can cause a high level of turnover intention. Other than that, the influence between the role of stress and turnover intention has not been fully explored especially the role of stress 
as a mediator between the influence of Leader-Member Exchange towards turnover intention.

When a person does kindness for other people, in accordance to the theory of social exchange people that give kindness expect it in return in the future from the person that kindness is given (Gouldner, 1960). Attitude and behavior of employees depends upon how much they feel balance in the social exchange process witin the work environment (Blau, 1964). Previous research has indicated that imperically the results of LMX is crucial (Kim dan Michàlle, 2014) when an individual employee feels the relationship is equal between their managers or supervisors, in turn employees will have job satisfaction for their work and can reduce the turnover intentions. However, continuos support depends on the relationship between the emotional connection, whilist leader-member exchange depends upon the quality of the interactive relationship(Shen et al, 2014).

Previous researches like Kim dan Michàlle (2014) put forward that when employees encounter stress within the work environment, employees will try to resolve or deal with stress by undertaking turnover. Hopkins et al, (2010) research stated that the work environment represents a main factor that contributes to initiating stress between employees. A different opinion that is put forward by Firth et al, (2004) has stated that the role of stress is not only effected by low job satisfaction towards work, but also a significant variable in which is that largest contributor towards turnover intention within organisations:

$\mathrm{H1}$ : Role of Stress significatly influences postively towards Turnover Intention; Exchange;

$\mathrm{H} 2$ : Role of Stress significatly influences negatively towards Leader-Member Intention.

H3: Leader-Member Exchange significatly influences negatively towards Turnover

Kim dan Michàlle (2014) concluded that when an employee feels the relationship is equal in between them and their superiors or supervisors, employees will have more job satisfaction and reduce the consideration to undertake Turnover Intention. In line with other researchers like Gerstner dan Day (1997) validated that a higher quality from LMX will improve the results attainment easier, improved job satisfaction and reducing the consideration to stop or quit work.

The research that is put forward by Hopkins et al, (2010) in which stated that the work environment and the role of stress represent the main factors towards the creation of stress between employees and ultimately resulting in turnover intentions. The same opinion was also stated by Firth et al, (2004) in which stated the role of stress does not only contribute to reducing job satisfaction towards work, but also a large contributor variable towards turnover intention within organisations. Other opinions that have been stated Desiana dan Soetjipto (2006), found that the role of stress that consists of role ambiguity, role conflict, and role overload significatly effect the influence of turnover intention for employees. Therefore, the hypothesis that are submitted are as follows:

$\mathrm{H}$ 4: Leader-Member Exchange (LMX) as a mediator for the Role of Stress influencing Turnover intention.

\section{METHODS OF RESEARCH}

This research will utilize Quantitative Design (Positivism) that is a research approach that works with numbers where the data is is created from data in form of tangible numbers. Quantitative approach uses statistics to answer and or test the hypothesis of this research that is specific in nature and can help predict that several variables. The quantitative approach uses statistics to answer questions or to test the hypothesis of this research that its nature is specific and to predict the relationship several variables effecting other variables. Testing the hypthesis is related to the relationship of the role of stress $\left(\mathrm{X}_{1}\right)$ towards Turnover Intention ( $\mathrm{Y}$ ) with the mediation from Leader-Member Exchange (M). This research utilizes quantitative method and associative forms.

This research is undertaken at cooperatives throughout the district of Tabanan. The consideration to select this location is because of the large number of employees that have a 
high intention to change companies on the merit of work loads that are given not in accordance with the given job description, and another aspect is that the level of growth for cooperatives in the district of Tabanan from in terms of productivity and assets are relatively high, thus its predicate has achieved by the district of Tabanan as the main activist of cooperatives in the year 2014.

The dependent variable in this research is Turnover Intention. The term Turnover Intention can be defined as the desire of employees to exit from a company, with the reason to find another employment that is better than the previous employment. Other than the dependent variable, this research also utilizes the dependent variable of the Role of Stress in which is defined as the sources of stress that are related towards hope above behaviour of employees that are positioned within the company. The other variables that are utilized in this research is the mediation variable that is Leader-Member Exchange in which is defined as the process of exchange that occurs between superiors and subordinates within an organisational setting.

The data that has been gathered for this research is categorised as quantitative data and qualitative data in the form of research questionaire, that is from the total number of cooperatives in the district of Tabanan. For the sources of data, the primary data that is utilized is from interviews, identity and answers from the respondents towards every single statement within the questionaire. The secondary data source for this research is from literature reviews, leading jurnals and internet websites to seach for more information that is related to the problems that are discussed within this research.

The population within this research is cooperatives in the district of Tabanan that in total 75 units. The method of obtaining samples for this research uses Probability Sampling technique whilist incorporating the method of Simple Random Sampling. Samples within this research are employees of cooperatives that are assessed and given the status for cooperatives as healthy, quite healthy and unwell for the year 2016 from the Cooperative Services and UKMK district of Tabanan.

The method of gathering data that will be utilized are interviews and questionaires. Interviews are utilized as a technique to gather data, in order to analyze the problem that is to be researched, and also for the researchers to fully understand the root problems related to the actual conditions of the population. The technique to gather data for applying within the questionaires is the technique that uses questions or written questions to the respondents to answer based of the perception of the respondents themselfs. The scale of the measurement that is applied within this research is the Likert Scale from a range of 1 (one) to 5 (five), where every answer is connected through a statement or supported by attitudes that are coveyed through words. Score 1 (one) on the likert scale indicates 'Strongly Disagree' (STS) and a score of 5 (five) for 'Strongly Agree' (SS)

The analysis models that are applied to complete the problems found in this research are The Discriptive Analysis and The Path Analysis. The problems that have to be answered are the direct influence The Role of Stress dan Leader-Member Exchange towards Turnover Intention, and the roles of mediation from Leader-Member Exchange on the relationships of the Role of Stress towards Turnover Intention. This research utilizes Structural Equation Modeling (SEM) with the approach of the variance based or component based with Partial Least Square (PLS).

An instrument is said to be valid if the correlation coeficient between questions is > 0.30 , and is considered reliable when the value of the Cronbach's Alpha is $\geq 0,60$. Overall, the validity of the tests have indicated that all variables have a correlated coeficient value with a total score larger than that of 0,30 . This situation indicates that the statements in this research instrument is considered valid. Other than that, the reliability test conditions for this research have been fulfilled, through the value of the Cronbach's Alpha $\geq 0,60$.

At the initial analysis stage, that is at the descriptive analysis, has indicated that the analysis can be divided into two (2) groups, which are indicators that are above the average variables and indicators that below the average variables. For the variable of the Role of Stress the average variable is as big as 2,57 , there is one indicator variable that is below the average of the Role of Stress and that is 'Role Overload' as big as 2,43 it is presumed that 
cooperatives that have resources (capital, goods and information) that is considered high in comparison to the the work responsibilities that are given to employees within the cooperatives.

To continue, there are two variable indicators that are above average which are the indicator for "Role Conflict" $\left(\mathrm{X}_{2}\right)$ as big as 2,66 and the indicator of "Role Ambiguity" $\left(\mathrm{X}_{3}\right)$ as big as 2,63.This matter can be percieved that employees within cooperatives in the district if Tabanan feel a high degree of responsibility that is given to them in comparison to their abilities, therefore quite often employees at cooperatives in the district of Tabanan recieve assignments outside the level of their responsibility that is given.

The variable Leader-Member Exchange overall has an average of 3,48 in which indicates that Leader-Member Exchange that is felt ny employees at cooperatives in the district of Tabanan are included in the criteria of good. The indicator that has become a trigger for the total average becoming good is at the indicator of "Contribution" $\left(\mathrm{M}_{4}\right)$ where this indicator has an average value as big as 3,83 in which indicates that contribution in achieving goals is considered good. However, there are three (3) indicator variables that have a below than average overall in which needs attention by the cooperatives which are the indicator of "Professional Respect" $\left(\mathrm{M}_{3}\right)$ as bing as 3,25; the next indicator is "Affection" $\left(\mathrm{M}_{2}\right)$ as big as 3,36; and the indicator of "Loyalty" $\left(\mathrm{M}_{1}\right)$ as big as 3,46.

The indicator for "Profesional Respect" is measured from how close the relationship between the superior and the subordinate from a professional viewpoint, in which has an average value which considered the lowest in comparison to the other questions as big as 3,25 . This means that the interactive relationship between lower level employees and superiors in the context of professional work is till not enough for the employees working within cooperatives in the district of Tabanan. Two (2) other indicators that are also below the average variable is "Affection" $\left(\mathrm{M}_{2}\right)$ dan "Loyalty" $\left(\mathrm{M}_{1}\right)$, can be percieved that concern given by superiors towards work being undertaken by employees at cooperatives is considered good enough, thus the defense that is given by superiors towards work that is given to employees working within cooperatives is also good enough.

The descriptive answer results by respondents for the variable of Turnover Intention of employees at cooperatives in the district of Tabanan are considered relatively high as big as 2,90 . The result achievement is relatively high which is contributed by one indicator that is above average variable which is employees that want to leave the company if given a chance $\left(Y_{5}\right)$ as big as 3,87 . This situation can be percieved that employees within cooperatives in the district of Tabanan will leave the company they are currently working at if the opportunity presents itself to find better employment elsewhere.

Turnover Intention for employees that is relatively high within the cooperatives in the district of Tabanan is formed by four (4) indicators that are below the average variables, which are trend of 'employees thinking of leaving the organisation' $\left(\mathrm{Y}_{1}\right)$ as big as 2,48 in which can be percieved that there is a low number of employees in cooperatives withiin the district of Tabanan that are thinking of leaving the company, the next variable is the 'possibility of employees to find new work at other organisations' $\left(\mathrm{Y}_{2}\right)$ is as bing as 2,59, which means there is a low number of employees seeking new work at other organisations in the cooperatives at the district of Tabanan; the third variable is 'employees that would like to leave their job in the near future $\left(\mathrm{Y}_{4}\right)$ as big as 2,75, this indicates a relatively high possibility of employees in within cooperatives in the district of Tabanan that would like to leave their company in the near future; the last variable is 'the possibility of employees to leave the company' $\left(\mathrm{Y}_{3}\right)$ as big as 2,80 , in which can be percieved that employees at cooperatives in the district of Tabanan will leave the company if there are offers from another company that may provide a higher wage.

At the second analysis stage which utilizes Structural Equation Modeling (SEM) with the approach of variance based or component based and with Partial Least Square (PLS) has obtained results in general that indicate the data of this research has met all valid standards in the outer model. The results are as follows: 


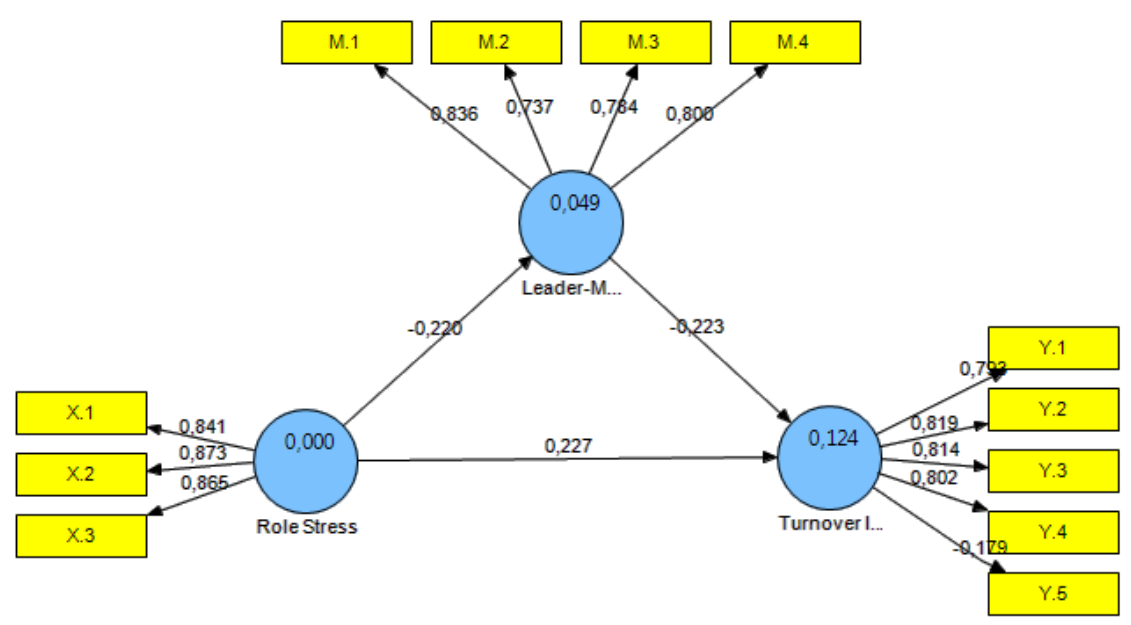

Figure 1 - Outer Model (Source: Processed Data, 2017)

The reliability composite value for the three (3) variables that make up the model of research has also indicated a result above 0,70 . However, one variable which is 'Turnover Intention" has a value of 0,797223 . This result indicates that each variable has fulfilled the composite reliability, thus can be concluded that all variables have a level of internal consistency that is high.

Table 3 - Test Result Composite Reliability

\begin{tabular}{cc}
\hline Variable & Composite Reliability \\
\hline Role Stress $(\mathrm{X})$ & 0,868832 \\
Leader-Member Exchange (M) & 0,894804 \\
Turnover Intention (Y) & 0,797223 \\
\hline
\end{tabular}

Source: processed data (2017).

The result from the convergent validity also indicate that the average in each indicator variable of this research has a value loading factor of more than 0,5 . However, there is still one (1) indicator that has a value loading factor less than $<0,5$ which is indicator $Y_{5}$ in which only has a value of $-0,179$. Therefore, it is assumed that the majority of the measurement indicators have fulfilled all the requirements of the convergence validity except indicator $Y_{5}$.

Table 4 - Test Results of Convergen Validity

\begin{tabular}{ccccc}
\hline Variable & Original sample estimate & Mean of subsamples & Standard deviation & T-Statistic \\
\hline Role Stress $(\mathrm{X})$ & & & & \\
$\mathrm{X}_{1}$ & 0,841 & 0,839 & 0,048 & 17,469 \\
$\mathrm{X}_{2}$ & 0,873 & 0,869 & 0,037 & 23,485 \\
$\mathrm{X}_{3}$ & 0,865 & 0,860 & 0,048 & 17,920 \\
Leader-Member Exchange (M) & & & \\
$\mathrm{M}_{1}$ & 0,836 & 0,819 & 0,141 & 5,944 \\
$\mathrm{M}_{2}$ & 0,737 & 0,727 & 0,104 & 7,113 \\
$\mathrm{M}_{3}$ & 0,784 & 0,766 & 0,109 & 7,169 \\
$\mathrm{M}_{4}$ & 0,800 & 0,778 & 0,140 & 5,710 \\
$\mathrm{Y}_{1}$ & & & & 10,390 \\
$\mathrm{Y}_{2}$ & 0,793 & 0,777 & 0,076 & 11,142 \\
$\mathrm{Y}_{3}$ & 0,819 & 0,798 & 0,073 & 9,744 \\
$\mathrm{Y}_{3}$ & 0,814 & 0,799 & 0,084 & 10,290 \\
$\mathrm{Y}_{3}$ & 0,802 & 0,786 & 0,078 & 0,861 \\
\hline
\end{tabular}

Source: Processed Data (2017). 
Other than that, the calculation results of the AVE have also shown that all values of AVE for the variables within this research are above 0,5 . It can be concluded that this measurement has met all requirements of discriminant validity and can be stated that every variable has achieved discriminant validity. As for the results of the convergent validity and discriminant validity can be seen in Tables 4 and 5 .

Table 5 - Test Results of Discriminant Validity

\begin{tabular}{cc}
\hline Variable & Average Variance Extracted (AVE) \\
\hline Role Stress $(\mathrm{X})$ & 0.623966 \\
Leader-Member Exchange $(\mathrm{M})$ & 0.739317 \\
Turnover Intention $(\mathrm{Y})$ & 0.527254 \\
\hline
\end{tabular}

Source: Attachment (Processed Data, 2017).

Testing of the Goodness of Fit (GoF) model for the structure for the inner model utilizes the value of $Q^{2}$ predictive-relevance $\left(Q^{2}\right)$. The value of $Q^{2}$ predictive-relevance can be obtained through a formula as follows:

$$
Q^{2}=1-\left(1-\mathrm{R}_{1}{ }^{2}\right)\left(1-\mathrm{R}_{2}{ }^{2}\right)=0,166523
$$

The calculation results have shown that the value of predictive-relevance is as big as $0,166523(>0)$. This means that if at 16,65 percent from turnover intention (dependent variabe/) variation can be described by the other variables that are applied within this model for this research, while the remainder of $83,35 \%$ can be described by other variables outside this model of research.

\section{RESULTS AND DISCUSSION}

The results of the empirical model of research utilizes a tool of analysis which is Partial Least Square (PLS) this produces results that can influence between variables as follows:

Table 6 - Test Results of the Research Hypothesis

\begin{tabular}{lcccc}
\hline \multicolumn{1}{c}{$\mathrm{n} / \mathrm{n}$} & Original sample estimate & Standard deviation & $\mathrm{t}$ - Statistic & Information \\
\hline Role Stress $\rightarrow$ Turnover Intention & 0.227 & 0.112 & 2,030 & significant \\
Role Stress $\rightarrow$ Leader-Member Exchange & $-0,220$ & $-0,243$ & 2,235 & significant \\
Leader-Member Exchange $\rightarrow$ Turnover Intention & $-0,223$ & $-0,238$ & 2,003 & significant \\
\hline
\end{tabular}

Source: Processed Data (2017).

Testing the hypothesis variable for Role of Stress towards turnover intention, permitted the result indicate that role of stress has a significant positif affect towards turnover intention. The results from testing the hypothesis with the PLS approach has produced a direct influence path coefficient role stress towards turnover intention with a value of $\beta$ as big as 0,227 and the t-statistics as big as 2,030. The value of the t-statistik as big as 2,030 is larger than that of 1,96 (t-critical value), has indicated that the influence role of stress towards turnover intention is significant. Therefore, the hypothesis has stated that the Role Stress has a positive significance towards Turnover Intention can be accepted. This matter indicates that the Role Stress has real influence in effecting Turnover Intention to employees at cooperatives in the district of Tabanan.

This result can be percieved that the higher the level of Role of Stress for employees in cooperatives in the district of Tabanan, it will result in the rise of the level of Turnover Intention that will occur, and vice versa. This is caused by the relatively high ambiguity of roles that is felt by employees of cooperatives in the district of Tabanan related towards the amount of workload given to employees at cooperatives that is outside their level of responsibilities. Besides that, there is also a conflict of roles that occurs within cooperatives 
in the district of Tabanan related to the unequal balance between ability and responsibilities that the employees have at the cooperative within the district of Tabanan.

The test results of the hypothesis have been proven positive and significant this is due to the majority of respondents are aged between 26-30 years old, so that has to be clarified in detail related towards responsibilities given to work that is designated. This matter will have an effect towards how employees think in order to deal with Role of Stress in the work environment, other than that with the level of clarity of roles which is designated by superiors of course this will effect the desire of people wanting to move to another company.

This research will develop further from the research undertaken by Hopkins et al. (2010) in this research stated that working environments and role of stress is the main factors that significantly influences stress between employees and leading to turnover intention. The same opinion was also put forward by Firth et al. (2004) the research found that role of stress does not only affect job satisfaction, but represents a large contributing variable towards turnover intention within organisations. Another opinion from the research conducted by Desiana dan Soetjipto (2006), found that the stressor role is made up of role ambiguity, role conflict, and role overload in which significantly has influence on turnover intention for employees.

Testing the hypothesis variable of Role Stress towards the variable of Leader-Member Exchange, has obtained results that the Role Stress has a negative significance towards Leader-Member Exchange. The results from testing the hypothesis by using the PLS approach has produced the influence path coefficients influencing directly the Role of Stress towards Leader-Member Exchange with a value $\beta$ as big as $-0,220$ and t-statistics as big as 2,235 . The t-statistics value of 2,235 is larger than that of 1,96 (t-critical value), thus the statement of the hypothesis has stated that the Role Stress has a negative effect and significance towards Leader-Member Exchange in which can be accepted. This situation signifies that a significant increase in the Role Stress can lead to reducing Leader-Member Exchange of employees at cooperatives in the district of Tabanan, and vice versa.

This situation indicates that if the Role Stress of employees in cooperatives increases, it can cause a decrease in the Lealder-Member Exchange at cooperatives in the district of Tabanan, and vice versa. The results from the description variable of this research also supports the hypothesis that states Role of Stress has a negative significance towards Leader-Member Exchange. The description variable of this research indicates that when there is a reduction from the indicator of affection and professional respect,there is a high probability it is caused by ambiguity roles and conflict roles that are encountered by employees in cooperatives in the district of Tabanan. This situation can lead to the reduction of the level of Leader-Member Exchange, in which Leader-Member Exchange represnts a process of exchange that occurs between superiors and subordinates within an organisation. Other cause that significantly effects this situation is caused by the majority of employees within cooperatives in the district of Tabanan have a high school education level, in which effects the level of knowledge for employees in regards to dealing with levels of Role Stress that is encountered when undertaking the work loads been given.

The results of this research is to expand the research put forward by Ariani (2011) in which the research stated that high Role Stress has a tendency to reduce the relationship interaction between superiors and subordinates within a company. Other research also indicated similar outcomes, in which according to Cherynyak dan Tziner (2014) stated that Role Stress has a significant influence towards Leader-Member Exchange. Opinions that have been stated by Graen dan Uhl-Bien (1995) stated that Leader-Member Exchange is based on the reciprocal relationship between workers and the organisation, in which there is a tendency for reciprocating kindness to the organisation, this includes the effort put forward to reduce the level of Turnover Intention.

The testing of the hypothesis on the influence of Leader-Member Exchange towards Turnover Intention, has produced results indicating that Leader-Member Exchange has a negative significance towards Turnover Intention. The test results of the hypothesis utilizing the PLS approach has produced direct influence path coefficients that Leader-Member Exchange has towards Turnover Intention with avalue $\beta$ as big as $-0,223$ and t-statistics 
2,003. The value of t-statistics is 2,003 in which is larger than that of 1,96 (t-critical value), therefore the influence of Leader-Member Exchange towards Turnover Intention is considered significant. From this, the hypothesis has showed that Leader-Member Exchange has a negative significance towards Turnover Intention is accepted. This situation is caused by the increase in Leader-Member Exchange that can reduce the Turnover Intention of employees in cooperatives in the district of Tabanan, and vice versa.

The results has shown the relationship significance as negative in which is caused by the Contribution indicator that gas shown average an average value that is highest. This has contributed to the situation where superiors with employees trying in achieving the same goals, are able to reduce the Turnover Intention of employees for cooperatives in the district of Tabanan. Other than that there is another contribution is from the Loyalty indicator can be interpreted in regards to the defense superiors have to subordinates in regards to assignments and work which are given. The significant and negative influence is due to the majority of respondents have a working period cycle of 3-7 years with the average ages between 26-30 years old and with a highschool education level, there is also a need to provide guidence and cooperation with supervisors, in order to create synergy between subordinates and supervisors to reduce the level of Turnover Intention.

This research tries to expand the previous research undertaken by Kim dan Michàlle (2014) where the results concluded that when an employee has an equal relationship between employees and leaders or supervisors, employees will enjoy their work and in turn reduce the level of Turnover Intention. In line with other researches like Gerstner dan Day (1997) validated that the higher the quality from the Leader-Member Exchange will make achiving results that are required by the job much more easier, improved work productivity, and reducing the level of employees having an intention to stop work. Bauer et al, (2006) also stated that the relationship between Turnover Intention and Leader-Member Exchange within the research undertaken, found that members that have quality exchanges that are considered low will have a low relationship with their leaders, inturn they will have an intention to exit higher than that of higher quality Leader-Member Exchange.

From testing the hypothesis it has been proven that the Role of Stress has a negative influence and significance towards Turnover Intention through partial mediation of LeaderMember Exchange. Role of Stress is still able to influence Turnover Intention of employees at cooperatives in the district of Tabanan with or without the variable of Leader-Member Exchange. The results of the calculations for the mediating role using the method put forward by Hair et al, (2010) through four steps, which are:

- Influence of Role of Stress $\rightarrow$ Turnover Intention on using the full model: indicated positive as big as 0,227 and is significant;

- Influence of Role of Stress $\rightarrow$ Turnover Intention on using the partial mode): indicated positive as big as 0,317 and is significant;

- Influence of Role of Stress $\rightarrow$ Leader-Member Exchange on using the full model: indicated as negative as big as 0,220 and is significant;

- Influence of Leader-Member Exchange $\rightarrow$ Turnover Intention on using the full model: indicated as negative as big as 0,223 and is significant.

From this, it can be explained that by using the full model, the influence of Role Stress towards Turnover Intention (1) is positive and significant; the influence of Role Stress towards Leader-Member Exchange (3) and Leader-Member Exchange towards Turnover Intention (4) is negative and significant. Whilist, by using the partial model it can be seen the influence the Role of Stress has towards Turnover Intention (2) is postive and significant.

Direct influence that is given by the Role of Stress towards Turnover Intention using the partial model is positif and significant as big as 0,317 . The value magnitude is relatively larger if compared to the direct influence that is given by the Role of Stress towards the Turnover Intention using the full model, which is as big as 0,227. From this, it can be concluded that Leader-Member Exchange act as a partial mediator in mediating the Role of Stress towards Turnover Intention. This means that the Role of Stress significantly can influence Turnover Intention directly or through mediation from Leader-Member Exchange. 
The variable of Leader-Member Exchange does not need to be too forced in its existence if the managers of cooperatives in the district of Tabanan itself is unable to reduce the level of the Role of Stress that is being encountered by employees in cooperatives in the district of Tabanan and provide influence that is positive towards reducing the level of Turnover Intention of employees. The role of Leader-Member Exchange is needed inorder to motivate managers at cooperatives in order to create reciprocal relationships between employees and the organisation, thus when employees feel the reciprocal relationship from the organisation, employees will have a tendency to reciprocate in in kindness to the organisation itself. The continuity of Leader-Member Exchange that is good within cooperatives can cause continuos improvements in the forseeable future. The results of this research is supported by several other results previously and consistently from research undertaken by Kim et al, (2014), Hopkins et al, (2010), Kim dan Stoner (2008), Bauer et al, (2006) in which indicated that Leader-Member Exchange mediates the influence of Role of Stress towards Turnover Intention.

\section{CONCLUSION}

The results of this research has provided implications to leaders or supervisors of cooperatives throughout the district of Tabanan to put more attention in regards to the relationships between superios and subordinates in order to reduce Turnover Intention. The cooperatives in the district of Tabanan are expected to reduce conflict of roles and ambiguity of roles that are encountered within cooperatives, in order to provide clarity in regards to work assignments and responsibilities that is given to every employee. This situation can be done through developing an accurate description of tasks in clarity and in writting regarding individual positions that are within the organisation

The respondents data has shown that the relationship that is considered professional between superiors and subordinates has the lowest score. This situation is caused by the large number of employees at cooperatives have a kinship relationship that is relatively strong within the leaders or supervisors of the cooperatives within the district of Tabanan. Therefore, the cooperatives is hoped to improve the levels of profesional respect, affection and loyality in order to reduce Turnover Intention in cooperatives within the district of Tabanan by undertaking a process of selection that is more selective rather than that of personal connections with the pontential employees at cooperatives.

For future researchers it is expected to consider other factors that have a relationship with the Role of stress, the Leader-Member Exchange, and the Turnover Intention like for example job satisfacton or even loyalty, and conduct research in the type of industry that is different and also different sized of companies. Other than that, future researchers should do variations in the analysis technique of the data, moderation analysis technique or other analysis techniques, in order to enrich the references for future research.

\section{REFERENCES}

1. Ahsan, M, Maidin, A, Sudirman, I, 2013. Pengaruh Kepuasan Kerja, Stress kerja, Variabel Organisasi dan Kepemimpinan Terhadap turnover Intention Karyawan Pada Rumah Sakit Pertamina Balikpapan. Tesis Jurusan Magister Manajemen Fakultas Ekomomi Universitas Hasanuddin.

2. Ariani, Wahyu D. 2011. Persepsi Terhadap Dukungan Organisasi dan Penyelia, Kepuasan, Nilai, dan Komitmen Pada Industri Perbankan di Indonesia. Jurnal Keuangan dan Perbankan, 15, pp: 416-427.

3. Bauer, T.N, Erdogan, B, Liden, R.C, Wayne, S.J, 2006. A longitudinal study of the moderating role of extraversion: leader-member exchange, performance, and turnover during new executive development. Journal of Applied Psychology 91, 298-310.

4. Berrin, Erdogan and Talya N Bauer. 2015. Leader-Member Exchange Theory. Portland State University, Portland, OR, USA.

5. Blau, P.M. 1964. Exchange \& power in social life. New York, NY: John Wiley \& Sons. 
6. Boushey, H, \& Glynn, S. J. 2012. There are significant business costs to replacing employees. diambil dari situs https: //www.americanprogress.org/wpcontent/uploads/2012/11/CostofTurnover.pdf diakses pada Tanggal 5, Bulan Februari, Tahun 2017

7. Cherynyak-hai, L, \& Tziner, A. 2014. Relationship between counterproductive work behavior, Perceived justice and climate, occupational status, and leader-member exchange. Journal of work and organizational psychology (JWOP), 30, pp: 1-12.

8. Desiana, P.M. dan Soetjipto, B.W. 2006. Pengaruh Role Stressor, Persepsi Dukungan Organisasi terhadap Kepuasan Kerja dan Komitmen, Usahawan, No. 05 Th. XXXV: pp: 22-32.

9. Detienne, K. B, Agle, B. R, Phillips, J. C, \& Ingerson, M. C. 2012. The impact of moral stress compared to other stressors on employee fatigue, job satisfaction, and turnover: An empirical investigation. Journal of Business Ethics, 110, pp: 377-391.

10. Firth, L, Mellor, M, Moore, K, Loquet, C. 2004. How can managers reduce employee intention to quit? Journal of Managerial Psychology 19(2). pp: 170-187.

11. Foa, E. B, \& Foa, U. G. 1974. Societal structures of the mind. Springfield, III: Charles C. Thomas.

12. Gerstner, C. R, \& Day, D. V. (1997). Meta-analytic review of leadere member exchange theory: correlates and construct issues. Journal of Applied Psychology. 82(6), pp: 827844.

13. Goolsby, J.R,1992. A theory of role stress in boundary spanning positions of marketing organizations.J.Acad.Mark.Sci. 20, pp: 155-164.

14. Gouldner, A. W. 1960. The norm of reciprocity: A preliminary statement. American Sociological Review, 25, pp: 161-178.

15. Graen, B George \& Mary Uhl-Bien. 1995. Relationship-Based Approach To Leadership: Development Of Leader-Member Exchange Theory Of Leadership Over 25 Years. Journal Leadership Quarterly 6 (2), pp: 209-247.

16. Graen, G. B, \& Cashman, J. F. 1975. A role-making model of leadership in formal organizations: A developmental approach. In J. G. Hunt \& L. L. Larson (Eds.).Leadership frontiers. Kent, $\mathrm{OH}$ : Kent State University Press.

17. Graen,B George \& Mary Uhl-Bien. 1995. Relationship-Based Approach To Leadership: Development Of Leader-Member Exchange Theory Of Leadership Over 25 Years. Journal Leadership Quarterly 6 (2), pp: 209-247.

18. Hair, J. F, W. C. Black, B. J. Bopin, and R. E. Anderson. 2010. Multivariate Data Analysis A Global Perspective (Seventh Edition). New Jersey: Pearson Education Inc.

19. Handoko, T, \& Hani. 2000. Manajemen sumber daya manusia (2 ${ }^{\text {nd }}$ ed.). Yogyakarta: Badan Penerbit Fakultas Ekonomi.

20. Harnoto. 2002. Manajemen Sumber Daya Manusia, Edisi kedua, PT. Prehallindo, Jakarta.

21. Hasibuan, Malayu S.P. 2014. Manajemen Sumber Daya Manusia. Jakarta: Penerbit Bumi Aksara.

22. Hopkins, K.M, Cohen-Callow, A, Kim, H.J, \& Hwang, J. (2010). Beyond intention to leave: Using multiple outcome measures for assessing turnover in child welfare. Children and Youth Services Review, 32, pp: 1380-1387.

23. Juniantara, Wayan. 2015. Pengaruh Motivasi dan Kepuasan Kerja Terhadap Kinerja Karyawan Koperasi di Denpasar. Tesis. Program Pascasarjana Universitas Udayana Denpasar.

24. Kahn, R.L, \& Quinn, R.P. 1970. Role stress: A framework for analysis. In A.McLean (Ed.), Mental health and work organizations (pp: 50-115). Chicago, IL: Rand McNally.

25. Kim, Ahraemi \& Michàlle E., Mor Barak. 2014. The mediating roles of leader-member exchange and perceived organizational support in the role stress-turnover intention relationship among child welfare workers: A longitudinal analysis. Children and Youth Services Review.

26. Kim, H, \& Stoner,M. 2008. Burnout and turnover Intention among social workers: Effect of role stress, job autonomy, and sovial support. Administration in social work, 32, pp: 5-25. 
27. Liden, R. C, \& Graen, G. 1980. Generalizability of the vertical dyad linkage model of leadership. Academy of Management, 23, pp: 451-465.

28. Liden, R. C, \& Maslyn, J. M. 1998. Multidimensionality of leader-member exchange: an empirical assessment through scale development. Journal of Management, 24, pp: 4372.

29. Lucas, S. (2012). How much does it cost companies to lose employees. MoneyWatch. Diambil dari: http: //www.cbsnews.com/news/how-muchdoes-it-cost-companies-to-loseemployees/ diambil tanggal 21, bulan Juni, tahun 2015.

30. Lum, L, Kervin, J, Clark, K, Reid, F, and Sirola, W. 1998. Explaining nursing turnover intention: Job satisfaction, pay satisfaction, or organizational comirment. Journal Of Organization Behaviour, 19 (3), pp: 305-320

31. Peraturan Menteri Koperasi Dan Usaha Kecil dan Menengah Republik Indonesia Nomor 15/Per/M.KUKM/IX/2015 tentang Usaha Simpan Pinjam Oleh Koperasi

32. Preacher, K. J, dan A. F. Hayes. 2004. SPSS and SAS Procedurer for Estimating Indirect Effects in Simple Mediation Models. Behavior Research Methods, Instruments \& Computers, Vol 36, No 4.

33. Robbins, Stephen P. dan Timothy A. Judge. 2008. Perilaku Organisasi (Organizational Behavior). Jilid 1, edisi 12. Jakarta: Penerbit Salemba Empat.

34. Shahzad, Khurram, Hayat, Khansa, Abbas, Muhammad, Bashir, Sajid, ur-Rehman, Kashif. 2011. Interdisciplinary. Journal of Contemporary Research In Business, pp: 108120.

35. Shen, Yimo, Jackson, Todd, Ding, C, Yuan, D, Zhao, L, Dou, Y, Zhang, Q. 2014. Linking perceived organizational support with employee work outcomes in a Chinese context: Organizational identification as a mediator. European Management Journal. pp: 406-412.

36. Sugiyono, 2014. Metodologi Penelitian Bisnis. Bandung: Alfabeta.

37. Widodo, R. 2010. Analisis Pengaruh Keamanan Kerja dan Komitmen Organisasional terhadap Turnover intention serta dampaknya pada kinerja karyawan outsourching (Studi pada PT PLN APJ persero Jogjakarta). Tesis program studi magister manajemen UNDIP.

38. Witasari, L. 2009. Analisis pengaruh kepuasan kerja dan komitmen organisasional terhadap intention to quit. Unpublished Master Tesis, Universitas Diponegoro, Semarang.

39. Yefei, Yang, Peter K.C.Lee, and Cheng, T.C.E.. 2015. Operational improvement competence and service recovery performance: The moderating effects of role stress and job resources. Journal Production Economics, 164, pp: 134-145.

40. Yukl, Gary. 2004. Leadership in Organizations (6th ed.). New Jersey: Prentice Hall.

41. Zulhartini, Sri. 2010. Pengaruh Pemutusan Hubungan Kerja Terhadap Karyawan Perusahaan. Jurnal Pendidikan Sosiologi dan Humaniora, 1(1), pp: 77-89. 